\title{
California Dreamin': the Future of Genomic Medicine
}

\author{
Elaine R. Mardis \\ Washington University School of Medicine, St. Louis, Missouri 63108, USA
}

The recent cold weather in St. Louis has me anticipating a trip in early March (3rd-4th) to sunny La Jolla, California, where I will attend and speak at the Future of Genomic Medicine (FOGM) IX meeting. As always, FOGM has a highly unique format that conveys the latest results from translational genomic (aka "precision") medicine, with the goal of aiding clinicians and researchers in making clinical decisions of individual patients more precise and personal. The meeting informs participants about how next-generation sequencing methods and analytical computational analyses can be combined for clinically relevant studies ushering genomics into evidence-based medicine. The meeting also provides perspectives on the social impact of genomic medicine as told by journalists, media personalities, and advocates. In the session on cancer, I will discuss our newest technological advances to understand the changes in DNA alterations and RNA expression that occur during cancer progression and provide specific examples from patients on how these data can influence clinical care.

The format of the meeting is a vibrant mixture of patient stories told by the patients themselves with the gentle coaxing of Dr. Eric Topol and faculty lectures that communicate current and cutting-edge approaches. The early morning introductory patient stories are always memorable and complement our vision at CSH Molecular Case Studies (MCS) to communicate important case studies in precision medicine. I was particularly moved by my colleague, Dr. Lukas Wartman, who discussed his own case with Dr. Topol at FOGM in 2012. Lukas was diagnosed with acute lymphoblastic leukemia (ALL) in 2003, and after being treated with a multidrug chemotherapy regimen, he suffered two relapses several years apart. At the time of the second relapse, he was able to enroll in a research study at Washington University School of Medicine, allowing next-generation sequencing of his bone marrow and ultimately identification of an apparent driver in the overexpression of FLT3, a druggable kinase target. By virtue of treatment with the corresponding therapy, Lukas was able to achieve complete remission and receive a lifesaving stem cell transplant. He has also written about his experience as both a patient and a cancer researcher in the inaugural issue of MCS.

Another unique aspect of the meeting is the participants. Attendees are an interactive, inquisitive group composed of academic researchers, community physicians, physicianscientists, pharmaceutical and biotechnology researchers, and undergraduates from local STEM programs. I always enjoy this meeting because it illustrates the current excitement, reality, and promise of precision medicine, and supports the idea that there is value in understanding individual patients and their disease from an " $N$ of 1 " perspective. This notion, of course, stands in stark contrast to the typical "one size fits all" approach that medicine has pursued for years and acknowledges the individual nature of diseases with a genetic component. With the journal's launch in the autumn of 2015, I will attend this year's meeting with a new purpose in mind. Much like FOGM, the journal provides a forum for communicating the results of translational medicine across the community of medical research and practice. Our aim is to encourage sharing of patient data broadly and rapidly and to reinforce the value of communicating " $N$ of 1 " cases so that our collective knowledge becomes an $N$ of many.

Published by Cold Spring Harbor Laboratory Press

doi: $10.1101 /$ mcs.a000976 


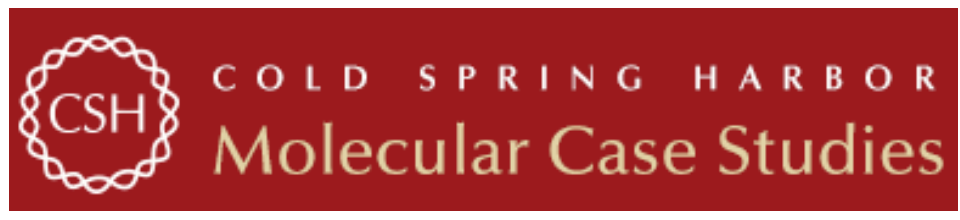

\section{California Dreamin': the Future of Genomic Medicine}

Elaine R. Mardis

Cold Spring Harb Mol Case Stud 2016, 2: a000976

Access the most recent version at doi: $10.1101 / \mathrm{mcs} . a 000976$

\begin{tabular}{cl}
\hline License & $\begin{array}{l}\text { This article is distributed under the terms of the Creative Commons } \\
\text { Attribution-NonCommercial License, which permits reuse and redistribution, except } \\
\text { for commercial purposes, provided that the original author and source are credited. }\end{array}$ \\
$\begin{array}{c}\text { Receive free email alerts when new articles cite this article - sign up in the box at the } \\
\text { Service }\end{array}$ & $\begin{array}{l}\text { Rep right corner of the article or click here. } \\
\text { toring }\end{array}$ \\
\hline
\end{tabular}

